\title{
Digestion of protein in the intestines of adult ruminants
}

\author{
By R. N. B. KaY, Rowett Research Institute, Bucksburn, Aberdeen
}

Interest in the digestive tract of ruminant animals has usually centred on the forestomach. This is natural enough, for the forestomach is the characteristic digestive organ of ruminants and about two-thirds of the digestible organic matter of the diet is fermented there (Harris \& Phillipson, I962; Bruce, Goodall, Kay, Phillipson \& Vowles, I966). Protein is extensively transformed in the rumen but amino acids are not absorbed from this site in any quantity. Unfortunately we know little about intestinal digestion of protein in ruminants.

An uneasy awareness of our neglect of the ruminant's intestines was often assuaged by supposing they differed little from those of better-known mammals, a guess which through repetition became elevated to the status of a reasonable assumption. It is now becoming clear that this guess was in many ways misleading; the capacity of the rumen and the metabolic activities of its micro-organisms affect the flow and composition of digesta passing to the intestines to an extent that makes intestinal digestion in ruminants a distinctive process.

For example: (I) Food is retained in the rumen for some hours and only flows to the lower gut slowly. (2) Microbial activity in the rumen transforms the diversity of protein in the diet to a more uniform product passing to the abomasum; it also removes most of the digestible carbohydrate from the food so that normally very little sugar is absorbed from the intestine. (3) The flow of digesta from the abomasum is enormous, almost continuous and fairly constant in consistency and composition; pancreatic secretion is equally continuous. (4) Abomasal secretion of acid is continuous and the intestinal contents remain acid throughout the upper part of the small intestine. (5) Large amounts of water and salts are secreted into the gut, especially by the salivary glands, and these must be efficiently reabsorbed, mostly in the small and large intestines.

The ruminant's intestines thus do not have to deal with the rather sudden inflows of food and water that pass to the duodenum in monogastric animals. Presumably intestinal digestion benefits in efficiency and economy from being a 'continuous' rather than a 'batch' process, though this concept has still to be placed on a factual footing.

\section{Digestion and synthesis of protein in the rumen}

The nitrogenous digesta flowing to the duodenum are largely of rumen microbial origin, though variously supplemented with unfermented food residues and digestive secretions. Before reviewing the little we know of protein digestion in the intestines and the conditions that may affect this, we must first consider briefly what protein is presented to the intestines for digestion. Phillipson (1964), Blackburn (1965) and McDonald ( 1968 ) have recently reviewed this subject from various points of view. Three factors are important: how much dietary protein evades 
degradation in the rumen and how much is degraded, the quantity and nature of the microbial protein synthesized from dietary and endogenous nitrogen and the amount of endogenous protein flowing to the duodenum.

Protein evading numal degradation. When the diet contains a lot of protein and little fermentable carbohydrate, the amount of protein degraded in the rumen exceeds the amount synthesized. Clarke, Ellinger \& Phillipson (I966), for example, found that when a ration of poor hay was supplemented with $15^{\circ} \mathrm{g}$ of soya protein, supplying $17 \mathrm{~g}$ of $\alpha$-amino nitrogen daily, a quarter of this amount disappeared before the duodenum was reached. Such losses may seriously curb protein synthesis and productivity by ruminants, and even under optimal conditions the amount and quality of microbial protein synthesized may be too little to allow the animal to achieve its full potential. Hogan \& Weston's (1967) experiments, for example, showed that the reason why two diets differing in protein content supported equal rates of wool growth was that, owing to the levelling effects of ruminal metabolism, almost equal amounts of protein were passing to the intestines; yet wool growth in such sheep can be almost doubled by infusing protein or sulphur-containing amino acids into the abomasum (Reis, I967).

The amount of dietary protein that evades degradation in the rumen depends on many conditions. Protein solubility is one of the most important: the less soluble a protein the less fully is it fermented. Recent research in Australia has aimed to increase the fraction of dietary protein reaching the intestines by treatment with formalin (Ferguson, Hemsley \& Reis, r967). Heating and drying the diet can have a similar effect (Beever, Thomson, Pfeffer \& Armstrong, 1969). The fractional clearance of fluid from the rumen (the percentage of the fluid volume passing to the omasum each hour) will clearly also influence the amount of protein that is flushed through the rumen before it can be fermented. Dietary roughage (Topps, Kay, Goodall, Whitelaw \& Reid, I968) and salt (Anonymous, I968) may be important in this respect. Yet another way to avoid microbial degradation of protein is suggested by Ørskov \& Benzie (I969). Lambs which had been trained to drink from a teat-bottle at weaning eagerly consumed fluid protein concentrates in this way, and such fluids passed directly to the abomasum by way of the oesophageal groove, thus by-passing the rumen altogether.

Proteins which pass into solution readily, such as casein or most of the protein in green forage, are rapidly hydrolysed by ruminal micro-organisms first to amino acids and then to ammonia. Ammonia that is not used for synthetic purposes by micro-organisms is absorbed from the rumen or downstream and takes no further part in protein metabolism unless it is used for synthesis of non-essential amino acids in the liver or is returned to the rumen as urea. Amino acid concentrations in the rumen are normally very low (vaz Portugal, I963) so that very little flow of free amino acids to the intestines takes place. No appreciable absorption of amino acids into the blood draining the rumen can be detected, even when rumen concentrations are greatly increased by addition of a casein hydrolysate (Annison, 1956). But some absorption of amino acids from the isolated perfused rumen has been demonstrated by Demaux, Le Bars, Molle, Rerat \& Simonnet (196I) and so this process 28 (I) 10 
might conceivably gain in importance under unusual feeding conditions. Microbial protein synthesis. Ammonia forms the main source of nitrogen for microbial protein synthesis, together with small amounts of amino acids, and this process is encouraged by the presence of plenty of digestible carbohydrate in the ration. Microbial fermentations in vitro, summarized by Hungate (1966), yield variable amounts of microbial protein, generally around $10 \mathrm{~g}$ for every $100 \mathrm{~g}$ organic matter fermented, and the yield depends to a marked extent on the nature of the carbohydrate substrate provided. This variation is to be expected, particularly since some micro-organisms are able to ferment substrates without corresponding cell growth.

A number of studies have been made of the composition and digestibility of rumen micro-organisms. Recently, for example, Purser \& Buechler (1966) found that the proportions of essential amino acids were much the same in each of ten bacteria and two protozoa, though the latter contained greater proportions of glutamic and aspartic acids. Not all of these amino acids are available to the host of course; a substantial fraction, probably associated with the cell wall, is indigestible.

A prodigious amount of work has gone into exploiting the ability of ruminal micro-organisms to use non-protein nitrogen for synthesis of protein. This has recently been reviewed by Chalupa (1968). The demonstration that a cow can be maintained in lactation on a purified diet whose only nitrogenous constituent is urea is perhaps the most impressive example of this ability (Virtanen, 1966). However, there have not been many direct measurements of the benefit of this process to the animal in terms of protein passing to the intestines.

Harris \& Phillipson ( 1962 ) showed that when hay diets containing only $7 \cdot 2 \mathrm{~g}$ nitrogen daily were given to sheep the amount of total nitrogen in the digesta flowing to the duodenum was 4 to $5 \mathrm{~g}$ greater than that in the food. Clarke $e t$ al. (I966) obtained similar results and showed that a net increase in $\alpha$-amino nitrogen between food and duodenal digesta accounts for at least half of the increase in total nitrogen, but suggest that secretion of nitrogen into the abomasum, which cannot lead to protein synthesis, might account for about $2 \mathrm{~g}$ of the total net increase occurring between mouth and duodenum.

Urea passes into the rumen both by way of the saliva (Somers, $196 \mathrm{r}$ ) and through the rumen wall (Houpt \& Houpt, 1968). Such a large part of the plasma urea is cycled to the rumen in these ways when the intake of nitrogen is low that protein hydrolysates (Moir \& Harris, 1962) or urea (Weston \& Hogan, 1967) have about as marked an effect on metabolism and ammonia concentrations in the rumen when infused into the abomasum as when given by mouth or by rumen fistula. Under some dietary conditions an infusion of urea into the rumen causes no increase in the amount of nitrogen, other than as ammonia, flowing to the duodenum, showing that endogenous secretions are supplying as much urea nitrogen as the microorganisms can use (Kay \& Phillipson, 1964).

The urea-ammonia-protein cycle is not restricted to ruminants. In man, urea nitrogen is incorporated into protein, probably as a result of microbial hydrolysis of urea in the gut followed by utilization of ammonia by the liver; even some 
essential amino acids may be synthesized in this way if the corresponding keto acid is included in the diet (Richards, Metcalfe-Gibson, Ward, Wrong \& Houghton, 1967 ).

\section{Nitrogenous constituents of the duodenal digesta}

The nitrogenous digesta at the duodenum consist of amino acids $(64-68 \%$ of total nitrogen), ammonia (5-10\% of total nitrogen) and an unidentified fraction (Clarke et al. I966). The last includes hexosamine (Badawy \& Mackie, 1964) and nucleic acids (Smith, McAllan \& Hill, I969).

The levelling effect of microbial protein metabolism on the proportions of amino acids in the protein reaching the duodenum is clearly demonstrated in the experiments of Clarke et al. (1966). Sheep were given a ration of poor hay alone or supplemented with flaked maize, soya protein, or both. These diets provided amino acids in very different proportions but in the duodenal contents the individual amino acids, as a percentage of total amino acids, varied over only roughly half the range found in the food. Besides providing a more consistent quality and quantity of protein, microbial activity also alters its quality. Although some amino acids, cystine and valine for example, constituted about the same fraction of duodenal protein as of food protein, others, such as proline, arginine and leucine, formed a smaller fraction while still others, such as lysine, threonine and isoleucine, formed a greater fraction. Bigwood (1964) also assessed the changes in dietary amino acids caused by rumen fermentation, by analysis of rumen contents in lactating cows, and reached similar conclusions. The rations given, roughage with roots and meals, themselves usually supplied too little of many essential amino acids (lysine, methionine, leucine, isoleucine and valine) to meet demands for maintenance and for secretion of milk, which is rich in lysine. Rumen fermentation compensated for almost all these deficiencies but at the same time caused a net degradation of proline and arginine. These changes illustrate how microbial modification of protein in the rumen moderatcs the effects of fluctuations in the amount and quality of protein consumed, and thus assumes some functions of the liver of monogastric animals. In an important sense microbial activity steps beyond hepatic function, since essential as well as non-essential amino acids are synthesized.

At present the ruminant's requirements for amino acids are poorly defined. It is not even certain that the essential amino acids that must be absorbed from the gut are the same as those required by the rat. As Lcwis \& D'Mello (r968) emphasize, the important feature of the dietary balance of amino acids is that it shall encourage the optimal proportions of amino acids to enter the cells synthesizing protein. Any serious departure from this balance, deficit or excess, may depress protein synthesis. Many barriers stand between the diet and these cells besides the rumen, such as the rate and extent of protein digestion in the intestine, characteristics of intestinal absorption of amino acids and their metabolism by the gut wall, permeability of blood vessels and cell membranes, and metabolic demands other than for protein synthesis. These barriers may vary substantially from species to species and so the amount 
and quality of protein that must be presented to the intestines to enable a given amount of protein to be synthesized will also vary.

\section{Control of acidity in the small intestine}

In man the acidity of the gastric contents is rapidly annulled in the duodenum and the $\mathrm{pH}$ of the intestinal contents reaches a value between 5.5 and 7.0 in the upper jejunum (Borgström, Dahlqvist, Lundh \& Sjövall, 1957). The position in sheep is quite different. Harrison \& Hill (1962) found the reaction of the duodenal contents to rise only gradually from a $\mathrm{pH}$ value of $2 \cdot 7$ at the pylorus to around 4 just beyond the entry of the common bile and pancreatic duct. Even $2 \mathrm{~m}$ further on in the upper jejunum the $\mathrm{pH}$ is only around 5 and neutrality is only reached in the lower jejunum (Lennox \& Garton, 1968).

Persisting acidity in the upper intestine of sheep can be attributed both to the copious secretion of acid in the abomasum (Phillipson, I952) and to the weakly alkaline nature of the secretions entering the intestine. The pyloric antrum and the glands of the duodenal mucosa each secrete about $500 \mathrm{ml}$ of fluid daily, but this has little neutralizing capacity (Harrison \& Hill, 1962). About $700 \mathrm{ml}$ of bile (Harrison, 1962) and $300-400 \mathrm{ml}$ of pancreatic juice (Magee, 1961; Taylor, 1962) are secreted daily, but in sheep, in contrast to the dog, these secretions contain little bicarbonate and their exclusion from the duodenum leads to a fall of only $0.34 \mathrm{pH}$ unit in the reaction of the contents (Harrison \& Hill, 1962).

A number of observations have recently been made at the Rowett Institute (R. N. B. Kay, unpublished observations) which confirm and extend these experiments. The results are summarized in Tables 1,2 and 3 . Seven sheep were fitted with one or two pairs of re-entrant cannulas in the small intestine, as described in Table r. These permitted both a study of the changing composition of the intestinal contents as they flowed distally and collection of intestinal secretions from the sheep having two pairs of cannulas. A ration of $800 \mathrm{~g}$ of pelleted dried grass was given daily from an endless-belt feeding device.

Table I. Position of re-entrant intestinal cannulas in sheep

\begin{tabular}{|c|c|c|c|}
\hline Sheep & Cannulas 1 and 2 & Cannulas 3 and 4 & $(\mathrm{~m})$ \\
\hline $\begin{array}{l}\mathrm{M} \\
\mathrm{X}\end{array}$ & $\begin{array}{l}0.05 \mathrm{~m} \text { beyond pylorus } \\
0.05 \mathrm{~m} \text { beyond pylorus }\end{array}$ & $\begin{array}{l}\text { None } \\
\text { None }\end{array}$ & \\
\hline $\mathrm{T}$ & $0.05 \mathrm{~m}$ beyond pylorus & $\mathrm{O} \cdot \mathrm{I} \mathrm{m}$ beyond bile duct & 0.5 \\
\hline $\mathbf{U}$ & $\begin{array}{l}0.5 \mathrm{~m} \text { beyond pylorus } \\
\text { (O.I } \mathrm{m} \text { beyond bile duct) }\end{array}$ & $\begin{array}{l}2.5 \mathrm{~m} \text { beyond pylorus } \\
\text { (17.5 m before caecum) }\end{array}$ & 2 \\
\hline $\mathbf{Y}$ & $2 \mathrm{~m}$ beyond pylorus & $\begin{array}{l}9 \mathrm{~m} \text { beyond pylorus } \\
\text { (ro } \mathrm{m} \text { before caecum) }\end{array}$ & 7 \\
\hline V & $7 \mathrm{~m}$ beyond pylorus & $\begin{array}{l}\text { I6.5 } \mathrm{m} \text { beyond pylorus } \\
(0.2 \mathrm{~m} \text { before caecum) }\end{array}$ & 9.5 \\
\hline I & $0.3 \mathrm{~m}$ before caecum & None & \\
\hline
\end{tabular}


Table 2. Flow of digesta through re-entrant intestinal cannulas in sheep receiving $800 \mathrm{~g}$ grass cubes daily from a continuous feeder (amount per $6 h \times 4$ )

\begin{tabular}{|c|c|c|c|c|c|c|c|}
\hline Sheep & Cannulas & $\begin{array}{l}\text { Flow } \\
(\mathrm{ml})\end{array}$ & $\begin{array}{l}\text { Total } \\
\text { nitrogen } \\
\text { (g) }\end{array}$ & $\mathrm{pH}$ & $\begin{array}{l}\text { Titratable } \\
\text { acid** } \\
\text { (m-equiv.) }\end{array}$ & $\begin{array}{l}\text { Total } \mathrm{CO}_{2} \\
\text { (m-moles) }\end{array}$ & $\begin{array}{l}\text { Inorganic } \\
\text { phosphate } \\
\text { (m-moles) }\end{array}$ \\
\hline $\mathrm{M}$ & $\mathbf{I}-2$ & 7560 & $24 \cdot 8$ & $2 \cdot 4$ & 801 & 7 & 252 \\
\hline $\mathrm{x}$ & $1-2$ & 5000 & 16.8 & $2 \cdot 4$ & 568 & 5 & 170 \\
\hline $\mathbf{T}$ & $1-2$ & 9570 & - & $2 \cdot 7$ & - & - & 156 \\
\hline & $3-4$ & 9470 & - & $4 \cdot 3$ & - & - & 100 \\
\hline $\mathrm{U}$ & $I-2$ & $533^{\circ}$ & $17 \cdot 3$ & 3.6 & $33^{6}$ & 9 & 75 \\
\hline & $3-4$ & 3990 & $14 \cdot 5$ & $4 \cdot 8$ & $15^{2}$ & 7 & 28 \\
\hline $\mathbf{Y}$ & $I-2$ & 6590 & 16.9 & $5 \cdot 2$ & 165 & II & 40 \\
\hline & $3-4$ & 4880 & II $\cdot 0$ & $7 \cdot 5$ & I I & 120 & 9 \\
\hline v & $I-2$ & 3360 & 10.6 & $7 \cdot 4$ & 26 & 75 & 4 \\
\hline & $3^{-4}$ & 2690 & $4^{\cdot I}$ & $8 \cdot 0$ & 8 & 142 & 3 \\
\hline I & $I-2$ & 2120 & $5^{\cdot 2}$ & $7 \cdot 8$ & 2 & 72 & 14 \\
\hline \multicolumn{8}{|c|}{${ }^{*}$ Titrated to $\mathrm{pH} 8}$. \\
\hline
\end{tabular}

Table 3. Secretion into empty loops of sheep small intestine (amount $/ 24 h)$

\begin{tabular}{|c|c|c|c|c|c|c|}
\hline Sheep & $\begin{array}{c}\text { Position and length } \\
\text { of loop }\end{array}$ & $\begin{array}{l}\text { Volume } \\
\text { (m1) }\end{array}$ & $\begin{array}{l}\text { Total } \\
\text { nitrogen } \\
\text { (g) }\end{array}$ & $\mathrm{pH}$ & $\begin{array}{c}\text { Total } \\
\mathrm{CO}_{2} \\
\text { (m-moles) }\end{array}$ & $\begin{array}{l}\text { Inorganic } \\
\text { phosphate } \\
\text { (m-moles) }\end{array}$ \\
\hline $\mathrm{T}$ & Duodenum, $0.5 \mathrm{~m}$ & $1380 *$ & $2 \cdot 0$ & $6 \cdot 9$ & 19 & 3 \\
\hline $\mathrm{U}$ & Upper jejunum, $2 \mathrm{~m}$ & 170 & 0.4 & 6.9 & I & 0 \\
\hline $\mathbf{Y}$ & Lower jejunum, $7 \mathrm{~m}$ & 270 & 0.5 & $7 \cdot 8$ & 18 & I \\
\hline $\mathrm{V}$ & Ileum, $9.5 \mathrm{~m}$ & 490 & 0.5 & $8 \cdot 0$ & 35 & $\circ$ \\
\hline
\end{tabular}

The flow of intestinal contents through the re-entrant cannulas was measured and sampled during $6 \mathrm{~h}$ periods; the measurements were made simultaneously from both pairs of cannulas in sheep T, U, Y and V. The results are shown in Table 2. A gradual increase in the $\mathrm{pH}$ of the contents was found which agrees well with previous reports. Titratable acid fell in a reciprocal manner and no substantial quantity of bicarbonate appeared before the lower jejunum was reached.

Under the conditions of this experiment the sheep were found to secrete about 31 . of saliva daily from each parotid gland. The saliva contained about $30 \mathrm{~m}$-moles inorganic phosphate/l., giving a daily secretion of some $180 \mathrm{~m}$-moles. Table 2 shows that a similar amount of phosphate passed into the duodenum, and that almost all was absorbed in the upper intestine. Phosphoric acid has a $\mathrm{pK}_{2}$ of $7 \cdot 15$ so that most of the phosphate absorbed from acid intestinal contents will be absorbed as dihydrogen phosphate (unless the intestinal epithelium selectively absorbs the monohydrogen form) and so will remove titratable acid from the digesta. However, absorption of some $200 \mathrm{~m}$-moles of dihydrogen phosphate daily only accounts for about $30 \%$ of the titratable acid which disappears from the upper intestine; the remainder is probably neutralized in situ.

In order to collect intestinal secretions from sheep $\mathrm{T}, \mathrm{U}, \mathrm{Y}$, and $\mathrm{V}$ digesta were made to bypass the loop by connecting cannula $\mathrm{I}$ to cannula 4 , the loop was rinsed and secretions were collected for $24 \mathrm{~h}$ as they were expelled from cannula 3 . The 
secretions collected from sheep $\mathrm{T}$ included bile and pancreatic secretion; $15 \%$ of the flow was retained for analysis and $85 \%$ infused into cannula 4 to avoid interfering greatly with digestion and the enterohepatic circulation of bile salts. The volumes and composition of the secretions are shown in Table 3 . The secretions from the duodenum and upper jejunum contained little bicarbonate whereas those from the lower jejunum and ileum were rich in bicarbonate, as found by Scott (I965). Very little phosphate was secreted. The secretions from the empty loop give a misleading impression of the capacity to secrete; when the loops were perfused with saline solution $(0.9 \% \mathrm{NaCl}, \mathrm{w} / \mathrm{v})$ at $3^{-5} \mathrm{ml} / \mathrm{min}$ the concentrations of bicarbonate in the outflowing perfusate were nearly as high as in secretions from the empty loop and thus the amounts secreted were much greater. The lower jejunal loop, for instance, added about $150 \mathrm{~m}$-moles total $\mathrm{CO}_{2}$ to the perfusate, enough to neutralize the acid digesta that normally entered it.

Acidity in the upper small intestinc may affect protein digestion in a number of ways. In the first place, acid conditions in the duodenum influence abomasal secretion (Ash, I96r) and also provide the main stimulus for pancreatic secretion (Magee, I96I) and so play a large part in regulating the secretion of proteolytic enzymes. Besides this, the slow rise in $\mathrm{pH}$ in the upper intestine may extend the activity of abomasal pepsin but delay the onset of activity of pancreatic enzymes. Pepsin is most active between $\mathrm{pH}$ I and 3 whereas pancreatic trypsin, chymotrypsin and peptidases all show optimal activity around or on the alkaline side of neutrality, and production of trypsin and chymotrypsin from their precursors only takes place above pH 5 (Boyer, Lardy \& Myrbäck, I960). Enzymes from the pancreas of the sheep seem to require the same $\mathrm{pH}$ for optimal activity as those from other species (Taylor, 1962). The acidity of the intestinal contents may also perhaps affect the absorption of aspartic and glutamic acids. These are exceptional among amino acids in that their absorption is brought about by passive diffusion rather than by an active mechanism (Wiseman, 1968). The $\mathrm{pK}$ values for dissociation of the second carboxyl group are 3.6 and $4 \cdot 2$ respectively, and so the acids will only acquire a second negative charge, altering their effective molecular size and their behaviour in an electrochemical gradient, as they pass through the upper jejunum. The effect of acidity on the activity of intestinal peptidases cannot even be guessed at, for these largely act in the micro-environment of the microvilli of the epithelial cells (Ugolev, I965), and beneath a protective film of mucus.

\section{Changes in nitrogenous fractions passing through the small intestine}

The ileal contents of sheep are even more constant in their content and proportions of amino acids than the duodenal contents. Clarke et al. (I966) found that between 3.4 and $9.8 \mathrm{~g}$ of $\alpha$-amino nitrogen were absorbed from the intestine, equivalent to about two-thirds of the amount present in the duodenal digesta. The actual amounts absorbed will be greater than these net values, since protein is also secreted into the small intestine. Owing to the decrease in the volume of digesta passing down the intestine the concentration of amino nitrogen in the ileal contents was no less than in duodenal contents when hay or hay with maize were given, but it was considerably 
less when the ration included soya protein. The proportions of amino acids in the ileum differed in many respects from those found in the duodenum; a marked increase in cystine, for example, suggests mucin secretion or microbial synthesis in the ileum. Increases were also noted in the proportions of threonine, glycine, alanine and proline, and decreases in lysine, leucine, isoleucine and arginine. Such changes show that the amino acid content of the duodenal digesta is not necessarily a good indication of the net quantities or proportions of acids absorbed; it is clear that what remains undigested or unabsorbed in the ileum is not simply a crosssection of the amino acids entering the small intestine.

When the gut contents of slaughtered sheep are analysed the concentrations of nitrogenous fractions and of organic matter relative to lignin are found to be much higher in the upper small intestine than they are in the abomasum or in the lower intestine (Boyne, Campbell, Davidson \& Cuthbertson, 1956; Rogerson, 1958). It was therefore supposed that very large amounts of endogenous protein are secreted into the intestine, but Badawy, Campbell, Cuthbertson, Fell \& Mackie (1958) discovered that this increase in nitrogen was an artifact, caused by the sloughing of large amounts of epithelium into the intestinal contents after death, and it was not found in living animals fitted with duodenal cannulas before or after the entrance of the common bile and pancreatic duct.

There is much variation from animal to animal in the flow and composition of intestinal digesta. A clearer picture can be gained from a single animal with two pairs of re-entrant intestinal cannulas at positions of interest than from two animals each with only one pair of cannulas at one or other position. Table 2 gives a few values obtained from sheep with one or two pairs of cannulas and these indicate the changes that take place in the amount of nitrogen in the digesta as they flow down the small intestine. Substantial amounts of nitrogen were absorbed from each part of the intestine, suggesting that net digestion of protein continues throughout the whole length of the small intestine. In man, on the other hand, the majority of digestible protein disappears from the upper jejunum, judging by the disappearance of plasma albumin (Borgström $\epsilon t$ al. r 957 ).

Experiments on such a small number of sheep need to be confirmed and extended before much reliance can be placed on them. Even so there are a number of independent studies which suggest, directly or indirectly, that hydrolysis and absorption of potentially digestible protein in the sheep's intestine may well be a relatively slow process. Not only are the proteins of plant and microbial residues likely to be refractory, but the amount of protease secreted by the pancreas is small compared to that in the dog (Taylor, 1962) and acidity in the upper intestine, as discussed above, may delay its action.

If in fact there is little or no safety margin for completion of protein digestion in the small intestine, the extent of digestion will depend to some degree on the time digesta are retained. This in turn is affected by diet; Coombe \& Kay ( 965$)$ have shown that retention times in the small intestine of sheep receiving dried grass or hay may vary from $4 \cdot 5$ to $2 \cdot 25 \mathrm{~h}$, the most rapid flow occurring when hay was given. 


\section{Secretion of nitrogen into the small intestine}

Nasset ( 1964 ) has championed the view that the secretion of protein into the gut maintains a more constant spectrum of amino acids and a larger pool of protein in the gut than would be the case were dietary protein not supplemented in this way, with beneficial effects on mucosal absorption of amino acids and on protein metabolism. A protein cycle of this sort is less relevant for ruminants, for ruminal metabolism already has these effects, but even so substantial amounts of nitrogen are secreted into the intestine of sheep. Cloete (1964), for example, found that even when a diet almost devoid of nitrogen was given to sheep the nitrogen content of the intestinal digesta was still a half of what was found when the diet was supplemented with casein.

Calculations based on the catabolism of ${ }^{\mathbf{1 3 1}}{ }^{\mathrm{I}}$-labelled albumin in the sheep suggest that a maximum of $8 \mathrm{~g}$ of plasma albumin enters the small intestine daily (Campbell, Cuthbertson, Mackie, McFarlane, Phillipson \& Sudsaneh, r96r). McDougall (I966) used sheep fitted with two pairs of intestinal re-entrant cannulas to measure secretion of protein into the intestine directly. About two-thirds of the protein secreted was soluble and one-third was associated with cellular debris. Threequarters of the soluble fraction consisted of plasma proteins and one-third of plasma albumin. An empty loop lacking the stimuli associated with the flow of digesta might be expected to secrete at an abnormally slow rate, and so secretion was stimulated by blowing air through the loops. While this increased the volume of fluid secreted the concentration of protein fell reciprocally so that protein secretion was unchanged. With one exception, jejunal loops $0.6-0.7 \mathrm{~m}$ in length were found to secrete protein at rates of $\mathrm{I}-5 \mathrm{~g} / 24 \mathrm{~h}$. Extrapolated to the assumed $\mathrm{I} 5 \mathrm{~m}$ length of the small intestine this suggested that $20-100 \mathrm{~g}$ protein were secreted daily, amounts so large that one doubts if the extrapolation should be made. Curiously, the amounts of protein secreted by such loops do not seem to depend on the length of the loop. In Table 3 it can be seen that loops of jejunum and ileum that were 2,7 and $9.5 \mathrm{~m}$ long each secreted only about $0.5 \mathrm{~g}$ nitrogen ( $3 \mathrm{~g}$ crude protein) daily; bile, pancreatic juice and duodenal secretion together contributed another $2 \mathrm{~g}$ nitrogen. Perfusion of these long loops with saline solutions $(0.9 \% \mathrm{NaCl}$, w/v) had little effect on the amounts of nitrogen secreted, despite greater volumes of contents, lower concentrations of protein and more rapid transit.

When such loops are washed out carefully and then perfused with saline solutions, urea accumulates in the perfusate at a rate related to the concentration of urea in the plasma (R. N. B. Kay \& D. T. Caridis, unpublished observations). If the loops are not thoroughly rinsed ammonia appears in the perfusate instead of urea. Presumably under normal conditions some of the ammonia absorbed from the gut originates in this way.

\section{Protein metabolism in the large intestine}

Although there have been a few reports of absorption of amino acids from the large intestine, such as from chronic loops of the dog's colon (Rhoads, Stengel, 
Riegel, Cajori \& Frazier, 1939) and from the isolated and perfused sheep's caecum (Demaux et al. 196r), it is generally supposed that such absorption is passive in nature and trivial in significance. If this is true for all species it poses interesting problems in protein metabolism for herbivores such as the horse, in which microbial digestion and synthesis is restricted to the large intestine and coprophagy is not practised, for when protein-deficient herbage is eaten the amounts of amino acids absorbed would surely be less then in ruminants. A back-flow of intestinal contents can often be seen in sheep which have re-entrant cannulas in the terminal ileum (R. N. B. Kay, unpublished observations) and this may allow absorption of some microbial amino acids from the ileum, but it seems unlikely to be of much importance.

Fermentation of food residues takes place in the large intestine of sheep with the production of considerable amounts of volatile fatty acids and ammonia, as in the rumen (Williams, I965; Faichney, 1968). Urea probably diffuses readily into the large intestine of ruminants, as it does into the rabbit's caecum (Houpt, I963), and nitrogen is secreted into isolated pouches made from the caecum and spiral colon of sheep at rates of about 0.1 and $0.2 \mathrm{~g} /$ day respectively (R. N. B. Kay, unpublished observations).

The net effect of secretion, microbial metabolism and absorption is the disappearance of about $0 \cdot 5^{-2} \mathrm{~g}$ of nitrogen daily from the digesta passing through the large intestine of sheep (Hogan \& Phillipson, I960; Goodall \& Kay, r965; Clarke et al. I 966). This is equivalent to as much as a third of the apparently digestible nitrogen of the ration. Even though the bulk of this nitrogen is probably absorbed as ammonia, much of it will be returned to the rumen when the nitrogen intake is low and so retrieval of nitrogen from the food residues in the large intestine may make a further contribution to protein metabolism.

Infusion of starch into the caecum of sheep can increase the amount of nitrogen excreted in the faeces and so reduce the apparent digestibility of dietary nitrogen (Ørskov \& Foot, 1969). This suggests that the amount of fermentable carbohydrate that normally reaches the large intestine may exert a considerable influence on apparent digestibility of nitrogen without necessarily having any effect at all on the amount of amino nitrogen absorbed.

\section{Summary}

In the rumen degradation of dietary protein and synthesis of microbial protein, some from non-protein nitrogen sources, ensure that the amount and quality of protein passing to the duodenum is more constant than that in the diet. In the small intestine itself the course of digestion may differ from that in monogastric animals: most of the protein is of microbial origin, the flow of digesta and secretion of digestive enzymes are continuous, acid conditions prevail along much of the jejunum and nitrogen disappears from the intestine throughout its length. The digestion of potentially digestible protein may not be taken to completion within the small intestine, though some residual nitrogen can be retrieved from the caecum and colon. 
Annison, E. F. (1956). Biochem. \%. 64, 705.

Anonymous. (1968). Rur. Res. C.S.I.R.O.6I.

Ash, R. W. (196r). \%. Physiol., Lond. 156, 93.

Badawy, A. M., Campbell, R. M., Cuthbertson, D. P., Fell, B. F. \& Mackie, W. S. (1958). Br. F. Nutr. 12,367 .

Badawy, A. M. \& Mackie, W. S. (1964). O. Il exp. Physiol. 49, 356.

Beever, D. E., Thomson, D. J., Pfeffer, E. \& Armstrong, D. G. (1 969). Proc. Nutr. Soc. 28,26 A.

Bigwood, E. J. (I964). In The Role of the Gastrointestinal Tract in Protein Metabolism, p. I 55. [H. N. Munto, editor.] Oxford: Blackwell Scientific Publications.

Blackburn, T. H. (1965). In Physiology of Digestion in the Ruminant, p. 322. [R. W. Dougherty, editor.] London: Butterworths.

Borgström, B., Dahlqvist, A., Lundh, G. \& Sjövall, J. (1957). F. clin. Invest. 36, I 521.

Boyer, P. D., Lardy, H. \& Myrbäck, K. (1960). The Enzymes. Vol. 4. New York and London: Academic Press Inc.

Boyne, A. W., Campbell, R. M., Davidson, J. \& Cuthbertson, D. P. (1956). Br. F. Nutr. 10, 325.

Bruce, J., Goodall, E. D., Kay, R. N. B., Phillipson, A. 'T. \& Vowles, T. E. (1966). Proc. R. Soc. B I66, 46 .

Campbell, R. M., Cuthbertson, D. P., Mackie, W., McFarlane, A. S., Phillipson, A. T. \& Sudsaneh, S. (196r). F. Physiol., Lond. 158, 1 13 .

Chalupa, W. (1968). 7. Anim. Sci. 27, 207.

Clarke, E. M. W., Ellinger, G. M. \& Phillipson, A. 'I. (七 g66). Proc. R. Soc. B x66, 63.

Cloete, J. G. (1964). Studies on metabolic faecal nitrogen excretion in sheep. DSc (Agric.) Thesis, University of Stellenbosch.

Coombe, J. B. \& Kay, R. N. B. (1965). Br. F. Nutr. 19, 325.

Demaux, G., Le Bars, H., Molle, J., Rerat, A. \& Simonnet, H. (1961). Bull. Acad. vét. Fr. 34, 85 -

Faichney, G. J. (1968). Aust. F. biol. Sci. 21, 177.

Ferguson, K. A., Hemsley, J. A. \& Reis, P. J. (1967). Aust. F. Sci. 30, 2 I 5.

Goodall, E. D. \& Kay, R. N. B. (1965). F. Physiol., Lond. 176, 12.

Harris, L. E. \& Phillipson, A. T. (I962). Anim. Prod. 4, 97.

Harrison, F. A. (1062). F. Physiol., Lond. 162, 212.

Harrison, F. A. \& Hill, K. J. (1962). F. Physiol., Land. 162, 225.

Hogan, J. P. \& Phillipson, A. T. (1960). Br. F. Nutr. 14, 147.

Hogan, J. P. \& Weston, R. H. (1967). Aust. F. agric. Res, 18, 973.

Houpt, T. R. ( ( 963$)$. Am. F. Physiol. 205, i I 44.

Houpt, T. R. \& Houpt, K. A. (1968). Am. Y. Physiol. 214, 296.

Hungate, R. E. (I 966). The Rumen and its Microbes. London: Academic Press Inc.

Kay, R. N. B. \& Phillipson, A. T. (1964). Proc, Nutr. Soc. 23, xlvi.

Lennox, A. M. \& Garton, G. A. (1968). Br. F. Nutr. 22, 247.

Lewis, D. \& D'Mello, J. P. F. (I968). In Growth and Development of Mammals, p. 345. [G. A. Lodge and G. E. Iamming, editors.] London: Butterworths.

Magee, D. F. (1961). \%. Physiol., Lond. 158, г 32.

McDonald, I. W. (1968). Aust. vet. F. 44, 145 .

McDougall, E. I. (1966). Biochem. F. 100, 19.

Moir, R. J. \& Harris, I. E. (1962). F. Nutr. 77, 285 .

Nasset, E. S. $\left(\mathrm{I}^{64}\right)$. In The Role of the Gastrointestinal Tract in Protein Metabolism, p. 83. [H. N. Munro, cditor.] Oxford : Blackwell Scientific Publications.

Orskov, E. R. \& Benzie, D. (Ig69). Proc. Nutr. Soc, 28, 30A.

Ørskov, E. R. \& Foot, M. H. (1969). Proc. Nutr. Soc. 28, 3 IA.

Phillipson, A. T. (1952). F. Physiol., Lond. 116, 84 .

Phillipson, A. T. (1964). In Mammalian Protein Metabolism. Vol. I, p. 7I. [H. N. Munto and J. B. Allison, editors.] New York: Academic Press Inc.

Purser, D. B. \& Buechler, S. M. (1966). F. Dairy Sci. 49, 81.

Reis, P. J. (1 967). Aust. F. biol. Sci. 20, 809.

Rhoads, J. E. Jr, Stengel, A. Jr, Riegel, C., Cajori, F. A. \& Frazier, W. D. (1939). Am. J. Physiol. 125, 707.

Richards, P., Metcalfe-Gibson, A., Ward, E. E., Wrong, O. \& Houghton, B. J. (I967). Lancet ii, 845 .

Rogerson, A. (1958), Br. F. Nutr. 12, 164.

Scott, D. ( ( 965$)$. Q. Fl exp. Physiol. 50, 3 r.2.

Smith, R. H., McAllan, A. B. \& Hill, W. B. (г969). Proc. Nutr. Soc. 28, 28A,

Somers, M. (196r). Aust. F. exp. Biol. med. Sci. 39, г23. 
Taylor, R, B. (1962). Res. vet. Sci. 3,63.

Topps, J. H., Kay, R. N. B., Goodall, E. D., Whitelaw, F. G. \& Reid, R. S. (1968). Br. Y. Nutr. 22, 281 .

Ugolev, A. M. (xg65). Physial. Rev. 45, 555.

vaz Portugal, A. (1963). Some aspects of protein and amino acid metabolism in the rumen of the sheep. $\mathrm{PhD}$ Thesis, University of Aberdeen.

Virtanen, A. I. (1966). Science, N.Y. 153, 1603.

Weston, R. H. \& Hogan, J. P. (1967). Aust. F. biol. Sci. 5, 967.

Williams, V. J. (1965). Aust. F. agric. Res. r6, 77.

Wiseman, G. (1968). In Handbook of Physiology. Section 6. Alimentary Canal. Vol. 3. [C. F. Code and W. Heidel, editors.] Washington, DC: American Physiological Society.

\section{Absorption of major minerals in the small and large intestines of the ruminant}

\section{By R. H. Sмiтн, National Institute for Research in Dairying, Shinfield, Reading}

There is no reason to suppose that the intestines of ruminants differ basically from those of most non-ruminants in the way in which they handle minerals. Special factors peculiar to ruminants are most likely to be found in the nature of their diet and the modifying effects of the alimentary tract before the abomasum on that diet.

\section{Exchange of sodium, potassium and chloride in the intestines and the regulation of water content of the digesta}

Sodium and potassium contents of digesta entering the duodenum of non-ruminants, including non-ruminating calves, are influenced both by the diet and by endogenous factors. Passage of digesta down the small intestine of non-ruminating calves leads to a regulation of $\mathrm{Na}$ to $\mathrm{K}$ ratio so that in the ileum it depends upon the $\mathrm{Na}-\mathrm{K}$ status of the animal and little or not at all upon the immediately preceding $\mathrm{Na}$ or $\mathrm{K}$ intake. Calves fed successively on Na-deficient and K-deficient synthetic milks showed marked changes in ileal $\mathrm{Na}$ and $\mathrm{K}$ concentrations only after $\mathrm{I}$ or 2 days on the new diet, when adaptation had taken place. Values for ileal $\mathrm{Na}$ to $\mathrm{K}$ mole ratio then varied from about 0.3 to $\mathrm{I}_{3}$ for $\mathrm{Na}$-deficient and $\mathrm{K}$-deficient diets respectively compared with normal values of about $3-7$ (Smith, 1966). Similar adaptation to a low Na intake has been shown for the dog (Field, Swell, Dailey, Trout \& Boyd, 1955).

The amounts of $\mathrm{Na}$ and $\mathrm{K}$ reaching the ileum are the final result of net secretion of $\mathrm{Na}$ into the duodenum and subsequent net absorption of $\mathrm{Na}$ and $\mathrm{K}$ in the rest of the small intestine (Mylrea, 1966 and Fig. I). $\mathrm{K}$ absorption is probably passive (Donnet, Jacquin \& Fondarai, I963; Gilman, Koelle \& Ritchie, r963) but for the calf is none the less very efficient, at least with diets containing as much $\mathrm{K}$ as does milk (Smith, I962; Mylrea, 1966). It has frequently been demonstrated that $\mathrm{Na}$ is actively absorbed (Parsons, 1967) and, although the mechanism is unclear, it 